\begin{tabular}{llrr}
\hline \hline Volume: & 3 & E-ISSN: & $2655-1942$ \\
Number: & 1 & Terbitan: & Mei 2020 \\
Page $:$ & $99-120$ & & \\
\hline
\end{tabular}

\title{
Praktik Ratifikasi Perjanjian Internasional Pasca Putusan Mahkamah Konstitusi Nomor 13/PUU-XVI/2018
}

\author{
Nanda Indrawati \\ Fakultas Hukum Universitas Atma Jaya Yogyakarta \\ Email : nanda.indrawati@uajy.ac.id
}

\begin{abstract}
Abstrak
Penelitian ini bertujuan untuk menganalisis Putusan Mahkamah Konstitusi Nomor 13/PUU-XVI/2018 perihal pengujian Undang-Undang Nomor 24 tahun 2000 tentang Perjanjian Internasional terhadap Undang-Undang Dasar Negara Republik Indonesia tahun 1945. Mahkamah Konstitusi dalam putusan tersebut hanya menerima satu permohonan pembatalan yaitu terhadap Pasal 10 UU Perjanjian Internasional. Putusan ini telah menimbulkan perkembangan yang baru terkait praktik proses ratifikasi perjanjian internasional di Indonesia. Namun di sisi lain, masih terdapat beberapa permasalahan terkait perluasan kriteria perjanjian internasional yang memerlukan persetujuan dari Dewan Perwakilan Rakyat. Hasil penelitian menunjukan bahwa sampai saat ini belum ada peraturan yang memberikan penafsiran terkait batasan kriteria perjanjian internasional yang proses pengesahannya memerlukan persetujuan dari Dewan Perwakilan Rakyat. Hal ini justru ini berpotensi akan menimbulkan permasalahan di kemudian hari karena adanya ketidakpastian hukum.
\end{abstract}

Kata Kunci: Ratifikasi; Perjanjian Internasional; Putusan Mahkamah Konstitusi

\begin{abstract}
This research aims to analyze the Constitutional Court Decision Number 13/ PUU-XVI/2018 regarding the judicial review of Law Number 24 of 2000 concerning International Treaties against the Constitution of the Republic of Indonesia 1945. The Constitutional Court decision received one revocation request against Article 10 of the Law on International Treaties. This constitutional court decision has arisen a new development related to the practice of the international treaties ratification process in Indonesia. However, this constitutional court decision remains an issue namely the expansion of the criteria for international agreements that require approval from the House of Representatives. The results of this research indicate that there has been no regulation provide interpretation on the restriction international treaties criteria that require approval from the House of Representatives in the ratification process. It potentially may cause some legal uncertainty problems.
\end{abstract}

Keywords: Ratification; Treaty; Constitutional Court Decision 


\begin{tabular}{llrr}
\hline \hline Volume: & 3 & E-ISSN: & $2655-1942$ \\
Number: & 1 & Terbitan: & Mei 2020 \\
Page $:$ & $99-120$ & &
\end{tabular}

\section{A. Latar Belakang Masalah}

Dewasa ini praktik hubungan internasional dirasakan semakin penting keberadaannya terlebih untuk mendukung adanya pembangunan dalam suatu negara. Sebagai anggota masyarakat internasional, suatu negara tidak dapat hidup tanpa adanya hubungan dengan anggota masyarakat internasional lainnya karena dilandasi kebutuhan timbal balik antar negara. Perwujudan hubungan internasional tersebut direalisasikan dalam bentuk perjanjian-perjanjian internasional. Mengenai substansi yang diatur dalam perjanjian-perjanjian internasional tidak hanya masalah-masalah yang ada di bumi saja, namun juga sudah meluas dengan mencakup objek-objek di luar planet bumi, seperti bulan, matahari, dan benda-benda angkasa lainnya. ${ }^{1}$

Pengaturan suatu masalah dalam suatu bentuk perjanjian internasional akan lebih menjamin adanya kepastian hukum sehingga memperkecil kemungkinan timbulnya persengketaan antar negara. Oleh karena itu dapat dikatakan bahwa perjanjian internasional memiliki peranan yang sangat penting dalam hubungan internasional. Bahkan tidak berlebihan jika dikatakan bahwa perjanjian internasional telah menggeser kedudukan dan peranan hukum kebiasaan internasional yang pada awal sejarah perkembangan hukum internasional menjadi sumber hukum utama hukum internasional. ${ }^{2}$

Secara umum pengaturan tentang perjanjian internasional diatur dalam dua konvensi internasional yaitu dalam Konvensi Wina 1969 yang mengatur perjanjian internasional dalam arti sempit yang pihaknya negara dengan negara, dan untuk perjanjian internasional yang pihaknya negara dan bukan negara misalnya organisasi internasional diatur dalam Konvensi Wina 1986. Pemerintah Indonesia sendiri sampai saat ini belum meratifikasi kedua konvensi tersebut namun pada faktanya pemerintah telah melaksanakan isi dari konvensi tersebut. Pengaturan secara khusus mengenai perjanjian internasional diatur dalam Undang-Undang Nomor 24 Tahun 2000 tentang Perjanjian Internasional (selanjutnya disebut UU Perjanjian Internasional).

\footnotetext{
${ }^{1}$ I Wayan Parthiana, 2018, Hukum Perjanjian Internasional Bagian I, Mandar Maju, Bandung, hlm.3

${ }^{2}$ Ibid, hlm.3
} 


\begin{tabular}{llrr}
\hline \hline Volume: & 3 & E-ISSN: & $2655-1942$ \\
Number: & 1 & Terbitan: & Mei 2020 \\
Page $:$ & $99-120$ & & \\
\hline
\end{tabular}

Salah satu tahapan penting dalam proses pembuatan perjanjian internasional yaitu proses ratifikasi. Persoalan ratifikasi ini bukan hanya persoalan hukum perjanjian internasional tetapi juga merupakan persoalan di bidang hukum tata negara. ${ }^{3}$ Praktik mengenai ratifikasi di Indonesia sampai saat ini agak tidak menentu. Dalam Undang-Undang Dasar Negara Republik Indonesia tahun 1945 bukan saja tidak terdapat pembagian perjanjian dalam golongan mana yang memerlukan dan tidak memerlukan persetujuan parlemen, bahkan tidak ditemukan kata ratifikasi itu sendiri apalagi terhadap pembedaaan antara persertujuan atau pengesahan terhadap perjanjian internasional. $^{4}$

Belum jelasnya pengaturan mengenai proses ratifikasi di Indonesia telah menimbulkan masalah tersendiri. Hal ini mendorong sekelompok masyarakat sipil untuk mengajukan judicial review terhadap beberapa pasal dalam UU Perjanjian Internasional yang dianggap tidak memberikan kepastian hukum bagi masyarakat. Pengujian tersebut khususnya terhadap Pasal 2, Pasal 9, Pasal 10, dan Pasal 11 UU Perjanjian Internasional. Mahkamah Konstitusi telah memberikan putusan atas judicial review tersebut melalui Putusan Mahkamah Konstitusi Nomor 13/PUU-XVI/2018. Para hakim MK dalam putusan tersebut hanya menerima satu permohonan pembatalan yaitu Pasal 10 UU Perjanjian Internasional. MK memutuskan bahwa Pasal 10 UU Perjanjian Internasional dinyatakan tidak berlaku sebab bertentangan dengan Pasal 11 ayat (2) dan Pasal 28 (D) UUD 1945.

Pasal 10 UU Perjanjian Internasional memberikan kriteria mengenai pengesahan perjanjian internasional yang dilakukan dengan undang-undang (perlu persetujuan DPR) apabila berkenaan dengan: 1) masalah politik, perdamaian, pertahanan, dan keamanan negara, 2) Perubahan wilayah atau penetapan batas wilayah negara, 3) Kedaulatan dan hak berdaulat negara, 3) Hak asasi manusia dan lingkungan hidup, 5) pembentukan kaidah hukum baru, 6) Pinjaman dan/atau hibah luar negeri. Setelah adanya putusan MK memberikan bahwa kriteria perjanjian internasional yang pengesahannya perlu mendapat persetujuan DPR sebagaimana yang diatur dalam Pasal 11 ayat (2) UUD 1945 yaitu "menimbulkan akibat yang luas dan mendasar bagi

${ }^{3}$ Mochtar Kusumaatmadja dan Etty R.Agoes,2013,Pengantar Hukum Internasional,PT.Alumni,Bandung, hlm.130

${ }^{4}$ Ibid, hlm.132 


$\begin{array}{llrr}\text { Volume: } & 3 & \text { E-ISSN: } & 2655-1942 \\ \text { Number: } & 1 & \text { Terbitan: } & \text { Mei } 2020 \\ \text { Page : } & 99-120 & & \end{array}$

kehidupan rakyat yang terkait dengan beban keuangan negara dan/atau mengharuskan beban keuangan negara, dan/atau mengharuskan perubahan atau pembentukan undang-undang."

Putusan ini telah menimbulkan perkembangan yang baru terkait praktik proses ratifikasi perjanjian internasional di Indonesia. Kriteria dalam Pasal 11 ayat (2) UUD 1945 memang lebih fleksibel dan memperluas kriteria perjanjian internasional yang memerlukan persetujuan DPR karena tidak terbatas pada 6 (enam) bidang yang ditentukan dalam Pasal 10 UU Perjanjian Internasional. Selain itu dengan adanya putusan ini dinilai memperluas kewenangan DPR sebagai wakil rakyat yang juga dapat diartikan memberikan hak kontrol serta partisipasi rakyat dalam proses ratifikasi perjanjian internasional. Namun ada hal yang menarik untuk dikaji lebih lanjut apakah dengan perluasan kriteria ini telah memberikan kepastian hukum dalam praktik ratifikasi perjanjian internasional di Indonesia.

\section{B. Metode Penelitian}

Sifat penelitian yang digunakan dalam penelitian ini adalah penelitian yang bersifat deskriptif. Penelitian deskriptif yakni penelitian yang bertujuan untuk menata dan mengklasifikasi gejala-gejala yang ada untuk mencapai kesempurnaan atas dasar bangunan permasalahan penelitian. ${ }^{5}$ Dalam hal ini penelitian hukum adalah proses untuk menemukan aturan hukum, prinsip - prinsip hukum, maupun doktrin hukum guna menjawab isu hukum yang dihadapi hal ini sesuai dengan karatekter prespektif ilmu hukum. ${ }^{6}$ Metode penelitian yang digunakan dalam penelitian ini yaitu penelitian hukum normatif. Penelitian hukum normatif yaitu penelitian hukum dengan cara meneliti bahan pustaka atau mempergunakan sumber data sekunder berupa bahan hukum primer dan sekunder. Untuk menjawab permasalahan dalam penelitian ini akan menggunakan bahan hukum primer yaitu berupa peraturan perundangundangan yang relevan yaitu Undang-Undang Dasar Negara Republik Indonesia tahun 1945 dan Undang-Undang Nomor 24 tahun 2000 tentang Perjanjian Internasional. Sedangkan bahan

\footnotetext{
${ }^{5}$ Maria SW. Sumardjono, 2014, Metodologi Penelitian Ilmu Hukum, Universitas Gadjah Mada, Yogyakarta, hlm. 7.

${ }^{6}$ Peter Mahmud Marzuki, 2008, Penelitian Hukum, Kencana Prenanda, Jakarta, hlm.35
} 


$\begin{array}{llrr}\text { Volume: } & 3 & \text { E-ISSN: } & 2655-1942 \\ \text { Number: } & 1 & \text { Terbitan: } & \text { Mei } 2020 \\ \text { Page : } & 99-120 & & \end{array}$

hukum sekunder yang akan digunakan yaitu berupa putusan pengadilan dan artikel ilmiah. Jenis pendekatan yang digunakan dalam penelitian ini yaitu pendekatan perundang-undangan (statute approach) dan pendekatan konsep (conseptual approach). Pendekatan perundang-undangan yang dimaksudkan bahwa peneliti menggunakan peraturan perundang-undangan sebagai dasar awal melakukan analisis. ${ }^{7}$ Sedangkan pendekatan konseptual yaitu konsep-konsep dalam ilmu hukum yang dijadikan titik tolak atau pendekatan bagi analisis penelitian hukum karena akan banyak muncul konsep bagi suatu fakta hukum. ${ }^{8}$ Selanjutnya, analisis data akan dilakukan secara kualitatif artinya dilakukan dengan menggambarkan, menjelaskan, serta menganalisis data yang diperoleh berdasarkan bahan-bahan hukum secara sistemik dan akurat. ${ }^{9}$

\section{Hasil Penelitian dan Pembahasan}

\section{Ketentuan Mengenai Ratifikasi Perjanjian Internasional}

Pasal 1 ayat (1) UU Perjanjian Internasional mendifinisikan perjanjian internasional adalah perjanjian dalam bentuk dan nama tertentu, yang diatur dalam hukum internasional yang dibuat secara tertulis serta menimbulkan hak dan kewajiban di bidang hukum publik. Perjanjian internasional menurut tahapan pembuatannya dapat dibedakan menjadi perjanjian yang dibuat dalam dua tahap yaitu tahap perundingan dan penandatanganan serta perjanjian yang dibuat dalam tiga tahap yaitu perundingan, penandatanganan, dan ratifikasi. Dalam pembuatan perjanjian yang dibuat dalam tiga tahap inilah ratifikasi menjadi salah satu tahapan yang sangat penting.

Proses ratifikasi menjadi suatu prosedur yang secara progresif dimulai pada abad XIX. Sebelumnya utusan Raja yang diberikan kekuasaan penuh dapat langsung menandatangani perjanjian dan langsung mengikatkan negara secara definitif. Namun dalam perkembangannya, prinsip modern hukum publik yang tidak menerima pelimpahan wewenang tanpa pengecekan maka dalam hal ini ratifikasi mempunyai arti yang penting. Pejabat negara memiliki wewenang

\footnotetext{
${ }^{7}$ Mukti Fajar dan Yulianto Achmad, 2010, Dualisme Penelitian Hukum Normatif dan Empiris, Pustaka Pelajar, Yogyakarta, hlm.185

${ }^{8}$ Ibid, hlm. 185

${ }^{9}$ Soerjono Soekanto, 2012, Pengantar Penelitian Hukum, Jakarta, Universitas Indonesia Press, hlm 32
} 


\begin{tabular}{llrr}
\hline \hline Volume: & 3 & E-ISSN: & $2655-1942$ \\
Number: & 1 & Terbitan: & Mei 2020 \\
Page $:$ & $99-120$ & &
\end{tabular}

treaty-making power untuk mengecek apakah utusan yang ditugaskan untuk berunding telah melaksanakan tugas sesuai dengan intruksinya atau tidak. ${ }^{10}$

Negara yang memberlakukan sistem respresentatif dimana badan-badan legeslatif dilibatkan dalam proses pembuatan perjanjian internasional, maka pengecekan kembali naskah perjanjian secara konstitusional dianggap perlu. Apabila tidak maka peranan parlementer dalam proses pembuatan perjanjian internasional tidak ada artinya karena mulai dari perundingan sampai pada penandatanganan hanya dilakukan oleh perwakilan negara dan tidak melibatkan badan legeslatif. Hal inilah yang menjadikan alasan bahwa ratifikasi dianggap perlu. ${ }^{11}$

Ratifikasi adalah perbuatan hukum lebih lanjut suatu negara untuk mengkonfimasi perbuatan penandatanganan yang telah dilakukan sebelumnya. ${ }^{12}$ Dalam praktek modern ratifikasi mempunyai arti lebih penting bukan saja sekedar konfirmasi saja namun juga merupakan pernyataan resmi suatu negara untuk terikat oleh perjanjian internasional. ${ }^{13}$ Ada kalanya, ratifikasi dipandang sebagai hal yang sangat penting tanpa ratifikasi suatu perjanjian internasional dianggap tidak akan efektif sebagai mana yang dikemukakan oleh Lard Stowel ${ }^{14}$

"Menurut praktik yang berjalan saat ini, ratifikasi merupakan syarat esensial; dan merupakan konfirmasi yang kuat tentang kedudukan ratifikasi. Bahwa setiap perjanjian internasional modern memuat syarat ratifikasi yang dinyatakan secara tegas; dan karena itu wewenang wakil dalam perundingan dibatasi oleh adanya syarat ratifikasi. Ratifikasi mungkin merupakan formalitas, namun formalitas yang esensial; karena merupakan instrument yang terkait dari segi keefektifan hukum, tidak lengkap tanpa keberadaannya."

Istilah ratifikasi dalam Pasal 1 ayat (2) Konvensi Wina 1969 disamakan dengan istilah “approval”, “acceptance”, dan "accession” yang mempunyai arti suatu tindakan untuk terikat pada perjanjian internasional. Praktik perjanjian internasional di Indonesia istilah ratifikasi

\footnotetext{
${ }^{10}$ Boer Mauna, 2015, Hukum Internasional Pengertian,Peranan, dan Fungsi dalam Era Dinamika Global, PT.Alumni, Bandung,hlm. 117

${ }^{11}$ Ibid, hlm 118

${ }^{12}$ Damos Dumoli Agusman, 2017, Hukum Perjanjian Internasional (Kajian Teori dan Praktik Indonesia), PT.Refika Aditama, Bandung, hlm.71

${ }^{13}$ J.G Starke yang diterjemahkan oleh Bambang Iriana Djajaatmaja, 2008, Pengantar Hukum Internasional 2, PT.Sinar Grafika, Jakarta, hlm.601

${ }^{14}$ Ibid, hlm 601
} 


\begin{tabular}{llrr}
\hline \hline Volume: & 3 & E-ISSN: & $2655-1942$ \\
Number: & 1 & Terbitan: & Mei 2020 \\
Page : & $99-120$ & & \\
\hline
\end{tabular}

diterjemahkan dengan istilah pengesahan sebagaimana dapat ditemukan Pasal 1 butir (2) UU Perjanjian Internasional yang menyatakan bahwa pengesahan adalah perbuatan hukum untuk mengikatkan diri pada suatu perjanjian dalam bentuk ratifikasi (ratification), aksesi (accession), penerimaan (acceptance) dan penyetujuan (approval).

Persoalan terkait kapankah suatu persetujuan untuk terikat pada perjanjian diatur dalam Pasal 14 Konvensi Wina 1969 yang mengatur bahwa persetujuan suatu negara untuk terikat pada suatu perjanjian dinyatakan dengan cara ratifikasi, apabila :

a. Perjanjian itu sendiri menentukan bahwa persetujuan untuk terikat pada perjanjian itu dinyatakan dengan cara ratifikasi.

b. Ditentukan sebaliknya bahwa negara-negara yang melakukan perundingan menyepakati bahwa dibutuhkan adanya ratifikasi.

c. Wakil dari negara yang telah menandatangani perjanjian tunduk pada tindakan ratifikasi; atau

d. Maksud dari negara yang menandatangani perjanjian tunduk pada tindakan ratifikasi yang tampak dari kuasa penuh dari wakilnya itu atau dinyatakan selama dalam perundingan.

Esensi dari tindakan ratifikasi yaitu merupakan suatu konfirmasi dari suatu fakta hukum yang mendahuluinya (yaitu perbuatan penandatanganan atau penerimaan naskah). Perkembangan selanjutnya tindakan ratifikasi ini dimaknai dengan maksud untuk memungkinkan adanya partisipasi publik untuk mempelajari terlebih dahulu perjanjian internasional. Menyusul perkembangan demokrasi yang ditandai dengan meningkatmya kekuasaan parlemen maka lembaga ratifikasi mulai dikenal dan berkembang dalam hukum nasional. Lembaga ratifikasi secara internal diartikan sebagai persetujuan parlemen terhadap rencana Kepala Negara untuk melakukan ratifikasi (mengikatkan diri) seperti yang dipersyaratkan oleh perjanjian internasional itu sendiri.

Dalam rangka menjernihkan konsepsi ratifikasi dari berbagai distorsi maka perlu dibedakan dua perbuatan hukum ini yaitu: ${ }^{15}$

\footnotetext{
${ }^{15}$ Ibid hlm 73
} 


\begin{tabular}{llrr}
\hline \hline Volume: & 3 & E-ISSN: & $2655-1942$ \\
Number: & 1 & Terbitan: & Mei 2020 \\
Page $:$ & $99-120$ & & \\
\hline
\end{tabular}

a. Perbuatan hukum internal yaitu persetujuan yang diberikan oleh organ negara (pada umumnya parlemen) kepada Kepala Negara/Kepala Pemerintah untuk melakukan pengikatan diri kepada suatu perjanjian, terlepas apakah berlakunya perjanjian ini harus melalui mekanisme ratifikasi atau tidak.

b. Perbuatan hukum eksternal yaitu ratifikasi oleh Kepala Negara/Pemerintah terhadap perjanjian yang mensyaratkan ratifikasi. Produk perbuatan ini berbentuk instrument of ratification yang ditandatangani oleh atau atas nama kepala Negara/Pemerintah.

Wayan Prathiana menyatakan bahwa ratifikasi sebagai bentuk pernyataan negara untuk mengikatan diri kepada suatu perjanjian internasional mengandung dua aspek yaitu aspek internal dan aspek eksternal. Aspek eksternalnya yaitu keterikatan suatu negara terhadap perjanjian dalam hubungannnya dengan negara lain. Sedangkan aspek internalnya yaitu terkait masalah di dalam negeri dari negara yang bersangkutan. Misalnya dalam hal organ manakah yang berwenang mengajukan persetujuan untuk terikat, bagaimana mekanismenya, serta konsekuensinya terhadap hukum nasional atas keterikatan perjanjian internasional. ${ }^{16}$

Pengaturan terkait aspek eksternal dalam ratifikasi perjanjian internasional tentu akan berbeda antara negara yang satu dengan lainnya. Oleh karena itu, meskipun dalam Konvensi Wina 1969 secara substansial telah mengatur mengenai ratifikasi namun secara detail bagaimana ratifikasi tersebut harus dilakukan oleh sebuah negara ditentukan oleh hukum nasional sesuai dengan sistem hukum, politik, maupun konstitusi masing-masing negara.

\section{Praktik Ratifikasi Perjanjian Internasional di Indonesia}

Landasan konstitusional yang berkenaan dengan perjanjian internasional di Indonesia diatur dalam Pasal 11 UUD 1945 yang menyatakan:

(1) Presiden dengan persetujuan Dewan Perwakilan Rakyat menyatakan perang, membuat perdamaian, dan perjanjian dengan negara lain.

\footnotetext{
${ }^{16}$ I Wayan Prathiana, Op.Cit hlm 144-145
} 


\begin{tabular}{llrr}
\hline \hline Volume: & 3 & E-ISSN: & $2655-1942$ \\
Number: & 1 & Terbitan: & Mei 2020 \\
Page $:$ & $99-120$ & &
\end{tabular}

(2) Presiden dalam membuat perjanjian internasional lainnya yang menimbulkan akibat yang luas dan mendasar bagi kehidupan rakyat yang terkait dengan beban negara, dan/atau mengharuskan perubahan atau pembentukan undang-undang harus dengan persetujuan Dewan Perwakilan Rakyat.

(3) Ketentuan lebih lanjut tentang perjanjian internasional diatur dengan undang-undang.

Ketentuan dalam Pasal 11 UUD 1945 ini sangat singkat sehingga pemerintah harus mengatur lebih jelas mengenai persoalan di bidang perjanjian internasional. Sebelum lahirnya UU Perjanjian Internasional, Pasal 11 UUD 1945 dijabarkan dengan Surat Presiden tanggal 22 Agustus 1960 Nomor 2826/HK/1960 yang ditujukan kepada ketua DPR, tentang pembuatan perjanjian dengan negara-negara lain. Surat presiden tersebut memberikan penafsiran ada dua macam bentuk perjanjian yang penting yang berbentuk traktat (treaties) dan yang kurang penting yang berbentuk perjanjian (agreements). Jadi ada dua cara pengesahan dari perjanjian internasional yaitu: ${ }^{17}$

a. Traktat (treaties) yang pengesahannya melalui DPR dengan undang-undang

b. Persetujuan (agreements) pengesahannya dengan keputusan presiden dan DPR cukup diberitahukan oleh Sekretariat Kabinet.

Secara hukum surat presiden tersebut tidak mempunyai kekuatan hukum karena apabila ditinjau dari tata urutan peraturan perundang-undangan maka surat presiden tidak masuk dalam tata urutan peraturan perundang-undangan. Namun, dalam praktiknya surat ini digunakan secara konsisten sehingga untuk kebutuhan praktik surat tersebut telah diterima menjadi konvensi tertulis di bidang ketatanegaraan di Indonesia. ${ }^{18}$ Dalam perkembangannya surat presiden ini dirasa kurang memberikan penjelasan dan sudah tidak sesuai dengan semangat reformasi maka diundangkan Undang-Undang Nomor 24 tahun 2000 tentang Perjanjian Internasional untuk lebih memberikan kepastian hukum dalam praktik pembuatan dan ratifikasi perjanjian internasional.

\footnotetext{
${ }^{17}$ Boer Mauna, Op.Cit, hlm.167

${ }^{18} \mathrm{Ibid}$, hlm 167
} 


\begin{tabular}{llrr}
\hline \hline Volume: & 3 & E-ISSN: & $2655-1942$ \\
Number: & 1 & Terbitan: & Mei 2020 \\
Page $:$ & $99-120$ & &
\end{tabular}

Istilah ratifikasi dalam UU Perjanjian Internasional diterjemahkan dengan istilah pengesahan dalam perspektif prosedur eksternal, yaitu perbuatan hukum untuk mengikatkan diri pada suatu perjanjian internasional dalam bentuk ratifikasi (ratification), aksesi (accession), penerimaan (acceptance) dan penyetujuan (approval). ${ }^{19}$ Pengesahan perjanjian internasional menjadi hukum positif di Indonesia menggunakan sistem campuran, yakni oleh badan eksekutif dan legeslatif dalam bentuk undang-undang atau keputusan presiden sebagaimana diatur dalam Pasal 9 ayat (2) UU Perjanjian Internasional. ${ }^{20}$ Presiden sebagai badan eksekutif memiliki kewenangan antara lain untuk membuat perjanjian internasional dengan negara lain sedangkan lingkup kewenangan DPR sebagai lembaga legeslatif mempunyai kewenangan untuk menyetujui atau menolak perjanjian internasional yang telah dibuat. ${ }^{21}$

Istilah "pengesahan" yang ada pada setiap sistem perundang-undangan di Indonesia bercampur aduk dengan istilah pengesahan dalam rangka undang-undang yang meratifikasi/mengesahkan perjanjian internasional. Maka istilah ini menimbulkan dua pemahaman yang berbeda yaitu: ${ }^{22}$

a. "Mengesahkan" diartikan sebagai persetujuan DPR. Pengesahan disini diartikan sebagai istilah undang-undang yang menandai bahwa persetujuan DPR seperti yang dimaksud oleh UUD 1945 disahkan.

b. Mengesahkan perjanjian internasional itu sendiri. Istilah pengesahan merupakan istilah ratifikasi internal yang ditujukan terhadap perjanjian internasional.

Pasal 11 UUD 1945 tidak menyebutkan secara tegas adanya kata ratifikasi dan tidak memberikan kejelasan prosedural mengenai tata cara meratifikasi suatu perjanjian internasional. Ketidakjelasan ini tentunya menimbulkan suatu permasalahan tersendiri dalam praktik ratifikasi perjanjian internasional di Indonesia. Sebagaimana yang diungkapkan oleh Mochtar

\footnotetext{
${ }^{19}$ Damos Dumoli Agusman, Op.Cit hlm.77

${ }^{20}$ Kamrmila Hippy, "Praktik Ratifikasi Perjanjian Internasional di Indonesia", Lex Administratum, Vol.I, No.2, April, 2013

${ }^{21}$ Ari Wiusang, "Kewenangan DPR dalam Ratifikasi Perjanjian Internasional Pasca Terbitnya Putusan Mahkamah Konstitusi No 13/PUU-XVI/2018”, Pakuan Law Review, Vol.5,No.2, Juli-Desember,2019.

${ }^{22}$ Damos Dumoli Agusman, Op.Cit hlm.82
} 


\begin{tabular}{llrr}
\hline Volume: & 3 & E-ISSN: & $2655-1942$ \\
Number: & 1 & Terbitan: & Mei 2020 \\
Page : & $99-120$ & & \\
\hline
\end{tabular}

Kusumaatmadja bahwa praktik ratifikasi di Indonesia agak tidak menentu. Bukan saja tidak terdapat pembagian perjanjian dalam golongan mana yang memerlukan dan tidak memerlukan persetujuan parlemen, bahkan dalam UUD 1945 kata ratifikasi itu sendiri tidak ditemui. ${ }^{23}$

Ketentuan dalam Pasal 11 UUD 1945 bersifat ringkas sehingga memerlukan penjabaran lebih lanjut. Untuk itu, pemerintah mengundangkan UU Perjanjian Internasional yang merupakan aturan pelaksana dari Pasal 11 UUD 1945. Pokok materi yang diatur dalam UU Perjanjian Internasional disusun dengan sistematika sebagai berikut :
a. Ketentuan Umum
b. Pembuatan Perjanjian Internasional
c. Pengesahan Perjanjian Internasional
d. Pemberlakuan Perjanjian Internasional
e. Penyimpanan Perjanjian Internasional

Sebagaimana telah disebutkab sebelumnya bahwa ratifikasi merupakan bagian terpenting dalam proses pembuatan perjanjian internasional. Ratifikasi perlu mendapatkan perhatian khusus mengingat bahawa pada tahapan ini suatu negara secara resmi mengikatkan diri pada perjanjian internasional. Salah satu permasalahan dalam proses ratifikasi perjanjian internasional di Indonesia yaitu tidak jelasnya perbedaan prosedur eksternal dan internal dalam tahapan ratifikasi. Hal ini terkait kapasitas DPR serta perwakilan yang diutus dalam pembuatan perjanjian internasional dalam membahas substansi perjanjian yang hendak diratifikasi serta tidak ada aturan yang jelas mengenai perlu tidaknya proses transformasi perjanjian internasional ke dalam perundang-undangan nasional.

Permasalahan ini yang mendorong permohononan gugatan materiil (judicial review) yang dilakukan oleh beberapa kelompok masyarakat ke Mahkamah Konstitusi. Para Pemohon mendalilkan bahwa ketentuan dalam Pasal 2, Pasal 9 ayat (2), Pasal 10, Pasal 11 ayat (1) dan penjelasan Pasal 11 ayat (1) UU Perjanjian Internasional inskonstitusional karena bertentangan

\footnotetext{
${ }^{23}$ Mochar Kusumaatmadja dan Etty R.Agoes, Op.Cit hlm.132
} 


$\begin{array}{llrr}\text { Volume: } & 3 & \text { E-ISSN: } & \text { 2655-1942 } \\ \text { Number: } & 1 & \text { Terbitan: } & \text { Mei } 2020 \\ \text { Page }: & 99-120 & & \end{array}$

dengan Pasal 11 ayat (2) UUD 1945. Pasal 11 UUD 1945 menggunakan istilah "persetujuan”, sementara UU Perjanjian Internasional menggunakan istilah "pengesahan" sehingga Pengugat mengangap bahwa peran DPR berubah dari yang seharusnya menyetujui atau menolak tindakan pemerintah yang mengikatkan diri kepada suatu kesepakatan internasional menjadi hanya pembuat pernyataan pengikatan (consent to be bound).

Mahkamah Konstitusi telah memutus pengujian judicial review UU Perjanjian Internasional tersebut melalui Putusan Mahkamah Konstitusi Nomor 13/PUU-XVI/2018. Putusan ini memberikan norma baru untuk memberikan penafsiran yang lebih lanjut ketentuan Pasal 11 UUD 1945. Kehadiran norma baru ini harus menjadi dasar hukum untuk mengembangkan ketentuan baru di dalam UU Perjanjian Internasional. Kementrian Luar Negeri menilai bahwa dengan adanya putusan ini juga memperkuat rencana revisi terhadap UU Perjanjian internasional. ${ }^{24}$

Mahkamah telah memberikan penafsiran yang sistematis terhadap Pasal 11 UUD 1945. Pasal 11 haruslah ditafsirkan bahwa frasa "perjanjian internasional lainnya" dalam Pasal 11 ayat (2) UUD 1945 menegaskan bahwa perjanjian antarnegara atau perjanjian dengan negara lainnya. Penegasan ini memberikan konsekuensi bahwa perjanjian internasional antarnegara dan perjanjian internasional antara negara dengan subjek hukum internasional lainnya yang bukan negara tunduk pada pengaturan yang berbeda. Perjanjian internasional antarnegara diatur oleh Konvensi Wina 1969 sedangkan perjanjian internasional yang antara negara dengan subjek hukum internasional lainnya diatur dalam Konvensi Wina 1986.

Dalam sistem hukum Indonesia tidak terlalu mengkonstuksikan secara tegas tentang perbedaan antara ratifikasi dalam dimensi hukum internasional dengan ratifikasi dalam hukum nasional. ${ }^{25}$ Dengan adanya Putusan Mahkamah Konstitusi tersebut telah memberikan pembedaan

24 Kontan, "Kementrian Luar Negeri: Putusan MK perkuat revisi UU Perjanjian Internasional" , https://nasional.kontan.co.id/news/kementerian-luar-negeri-putusan-mk-perkuat-revisi-uu-perjanjianinternasional, diakses pada 10 Februari 2020 jam 15.00 wib

${ }^{25}$ Damos Dumoli Agusman, "Status Hukum Perjanjian Internasional dalam Hukum Nasional RI Tinjauan Dari Perspektif Praktik Indonesia", Indonesian Journal of International Law, Vol 5 No 3, April 2008, hlm 493 


$\begin{array}{llrr}\text { Volume: } & 3 & \text { E-ISSN: } & \text { 2655-1942 } \\ \text { Number: } & 1 & \text { Terbitan: } & \text { Mei } 2020 \\ \text { Page }: & 99-120 & & \end{array}$

mengenai makna pengesahan yang selama ini diperdebatkan oleh para pakar yaitu apakah “persetujuan DPR" dan "pengesahan” adalah satu kesatuan proses atau dua proses yang berbeda. Selama ini pemerintah berpendapat bahwa berdasarkan UU Perjanjian Internasional mengartikan kedua istilah tersebut merupakan suatu kesatuan proses, yaitu bahwa "persetujuan DPR" yang diekspresikan melalui undang-undang pengesahan. ${ }^{26}$ Putusan Mahkamah Konstitusi telah membedakan pengertian pengesahan perjanjian internasional menurut hukum internasional dan pengesahan menurut hukum nasional. Persetujuan DPR diperlukan apabila suatu perjanjian internasional yang memenuhi kriteria sebagaimana dimaksud dalam Pasal 11 ayat (2) UUD 1945. Sedangkan pengesahan dalam arti ratifikasi yang merupakan persetujuan untuk terikat pada perjanjian internasional berkaitan dengan jenis perjanjian internasional berdasarkan tahapan pembuatan perjanjian internasional tersebut.

Perjanjian internasional menurut tahap pembuatannya dibedakan menjadi dua yaitu perjanjian internasional dua tahap dan tiga tahap. Perjanjian internasional dua tahap terdiri dari tahapan perundingan (negotiation) dan tahapan penandatanganan (signature). Sedangkan, perjanjian internasional tiga tahap terdiri dari tahap perundingan (negotiation), tahap penandatanganan (signature), dan tahapan pengesahan (ratification). Hal yang membedakan antara perjanjian dua tahap dan tiga tahap yaitu mengenai arti penting tahap penandatanganan (signature). Penandatanganan perjanjian dalam perjanjian dua tahap dimaknai sebagai pernyataan untuk terikat pada suatu perjanjian internasional (consent to be bound). Sedangkan, dalam perjanjian internasional yang terdiri dari tiga tahap penandatanganan hanya merupakan penyataan bahwa para wakil para pihak dalam perundingan telah mencapai kesepakatan mengenai masalah yang dirundingkan (adoption of text), bukan sebagai pernyataan untuk terikat. Oleh karena itu diperlukan satu tahap lagi yaitu ratifikasi supaya perjanjian yang telah ditandatangani dapat mengikat para pihak.

\footnotetext{
${ }^{26}$ Hukum online, "Putusan MK UU Perjanjian Internasional:Apa yang diubah", https://www.hukumonline.com/berita/baca/lt5c79077b8ebcb/putusan-mk-uu-perjanjian-internasional--apa-yangdiubah-oleh--damos-dumoli-agusman/, “, diakses pada tanggal 12 Januari 2019 pukul 17.00 wib
} 


\begin{tabular}{llrr}
\hline \hline Volume: & 3 & E-ISSN: & $2655-1942$ \\
Number: & 1 & Terbitan: & Mei 2020 \\
Page $:$ & $99-120$ & & \\
\hline
\end{tabular}

Dalam tahapan ratifikasi inilah terdapat keterkaitan antara persetujuan untuk terikat dalam suatu perjanjian internasional dengan pengesahan perjanjian internasional menurut hukum nasional. Dalam praktik banyak negara yang masih menyamakan istilah ratifikasi dari dimensi internasional dan dimensi hukum nasional. Suatu negara dinyatakan secara sah terikat dalam suatu perjanjian internasional apabila telah meratifikasi perjanjian internasional sesuai dengan prosedur dan tata cara yang berlaku menurut hukum nasionalnya.

Pengesahan menurut hukum internasional merupakan pernyataan terikat dalam suatu perjanjian internasional. Sedangkan, pengesahan dalam konteks hukum di Indonesia adalah merujuk pada tindak lanjut dari tahapan pembuatan perjanjian internasional yang mempersyaratkan adanya pengesahan. Pasal 9 ayat (2) UU Perjanjian Internasional menyatakan bhawa pengesahan itu dilakukan dengan undang-undang atau keputusan presiden. MK berpendapat bahwa meskipun dalam UUD 1945 tidak menentukan adanya bentuk hukum tertentu dari persetujuan DPR, menurut penalaran yang wajar, ada atau tidaknya persetujuan DPR dapat diketahui dari hasil pelaksanaan tahapan konsultasi yang pada akhirnya akan tercermin dari disahkan atau tidaknya suatu perjanjian internasional (Halaman 260 Putusan MK No 13/PUU-XVI/2018). Dalam tahapan konsultasi tersebut DPR akan memberikan rekomendasi kepada Presiden. Secara hukum rekomendasi memang tidak mengikat, namun dalam praktik hal ini sangat dihormati oleh Pemerintah.

Mekanisme konsultasi ini memberikan keleluasan kepada Presiden dalam melaksanakan fungsinya pemerintahannya. Fungsi pemerintahan berkaitan dengan masalah-masalah hubungan internasional dengan tetap menempatkan kepentingan nasional juga mempertimbangkan kaidahkaidah yang diterima secara universal oleh masyarakat internasional. Selain itu, mekanisme ini memberikan memenuhi fungsi pengawasan oleh DPR tanpa menghambat keleluasaan bergerak Presiden. Dengan demikian putusan MK ini telah membedakan antara persetujuan DPR seperti yang dimaksud dalam Pasal 11 UUD NRI Tahun 1945 dengan pengesahan menurut hukum nasional yaitu dengan undang-undang pengesahan. Kedua proses ini merupakan dua proses yang 


$\begin{array}{llrr}\text { Volume: } & 3 & \text { E-ISSN: } & 2655-1942 \\ \text { Number: } & 1 & \text { Terbitan: } & \text { Mei } 2020 \\ \text { Page : } & 99-120 & & \end{array}$

berbeda. Persetujuan DPR dapat terekspresi dalam bentuk rekomendasi, sedangkan persetujuan DPR merupakan pengesahan hukum nasional yang terekpresi dengan lahirnya UU pengesahan.

Mahkamah Konstitusi juga memberikan makna baru terhadap UU pengesahan yaitu sebagai instrument yang memberlakukan perjanjian internasional ke dalam hukum nasional. Hal ini telah memberikan penjelasan terhadap tafsir makna UU pengesahan yang selama ini salah kaprah. Selama ini, UU pengesahan dimaknai sebagai bentuk persetujuan DPR kepada pemerintah untuk terikat pada suatu perjanjian. Dalam praktiknya keterikatan Indonesia pada suatu perjanjian tidak tergantung pada adanya UU pengesahan saja melainkan tergantung pada adanya piagam ratifikasi serta aturan yang ditetapkan pada perjanjian internasional itu sendiri. ${ }^{27}$ Sekalipun Indonesia telah mengeluarkan UU pengesahan dan telah menyampaikan piagam ratifikasi, suatu perjanjian belum tentu serta merta berlaku jika terdapat syarat jumlah ratifikasi untuk mulai pemberlakuannya. Hal ini mungkin terjadi dalam hal apabila pada saat Indonesia menyampaikan piagan ratifikasi jumlah negara yang menyampaikan piagam ratifikasi, jumlah negara yang melakukan ratifikasi belum memenuhi syarat.

Konsekuensi dari persyaratan jumlah ratifikasi untuk mulai pemberlakuan perjanjian internasional maka berlakunya UU pengesahan tidak selalu identik dengan mulai berlakunya perjanjian internasional terhadap Indonesia. Sebagai contoh Indonesia telah melakukan ratifikasi terhadap United Nations Conventions on the Law of the Sea 1982 (UNCLOS 1982) dengan Undang-Undang Nomor 17 tahun 1985 pada tanggal 31 Desember 1985 kemudian menyampaikan piagam ratifikasi kepada Sekretaris Jenderal PBB pada tanggal 3 Februari sedangkan UNCLOS 1982 baru mulai berlaku pada tanggal 16 November 1994 setelah syarat syarat jumlah ratifikasi untuk mulai pemberlakuannya terpenuhi.

Terhadap dalil permohonan yang diajukan judicial review ketentuan dalam Pasal 2, Pasal 9 ayat (2), Pasal 10, Pasal 11 ayat (1) UU Perjanjian Internasional. Mahkamah Konstitusi dalam putusannya hanya mengabulkan permohonan Pasal 10 UU Perjanjian Internasional. MK

\footnotetext{
${ }^{27}$ Damos Dumoli Agusman, Op.Cit, hlm.82
} 


\begin{tabular}{llrr}
\hline \hline Volume: & 3 & E-ISSN: & $2655-1942$ \\
Number: & 1 & Terbitan: & Mei 2020 \\
Page $:$ & $99-120$ & &
\end{tabular}

menyatakan bahwa Pasal 10 UU Perjanjian Internasional bertentangan dengan UUD 1945 dan tidak mempunyai kekuatan hukum mengikat secara bersyarat sepanjang ditafsirkan bahwa hanya jenis-jenis perjanjian internasional tertentu harus mendapat persetujuan dari DPR dengan instrumen UU Pengesahan.

Pasal 10 UU Perjanjian internasional mengatur bahwa pengesahan perjanjian internasional harus dilakukan dengan persetujuan DPR apabila berkenaan dengan:
a. Masalah politik, perdamaian, pertahanan, dan keamanan negara;
b. Perubahan wilayah atau penetapan batas wilayah negara;
c. Kedaulatan dan hak berdaulat negara;
d. Hak asasi manusia dan lingkungan hidup;
e. Pembentukan kaidah hukum baru;
f. Pinjaman dan/atau hibah luar negeri;

Dalam amar putusannya MK menyatakan bahwa Pasal 10 UU Perjanjian Internasional bertentangan dengan UUD 1945 dan tidak mempunyai kekuatan mengikat secara bersyarat sepanjang ditafsirkan bahwa hanya jenis-jenis perjanjian internasiomal sebagaimana disebutkan pada huruf a sampai dengan f dalam Pasal a quo itulah yang mempersyaratkan persetujuan DPR sehingga hanya jenis-jenis perjanjian tersebut yang pengesahannya dilakukan dengan undangundang (halaman 266 Putusan MK Nomor 13/PUU-XVI/2018).

Putusan tersebut dapat diartikan bahwa pengkategorian Pasal 10 UU Perjanjian Internasional tidak cukup memaknai perjanjian internasional sebagaimana yang diatur dalam Pasal 11 ayat (2) UUD 1945. Kriteria perjanjian internasional yang membutuhkan persetujuan dalam Pasal 11 ayat (2) UUD 1945 yaitu "menimbulkan akibat yang luas dan mendasar bagi kehidupan rakyat yang terkait dengan beban keuangan Negara dan/atau mengharuskan perubahan atau pembentukan undang-undang". Dalam dalil gugatan pemohon menyampaikan bahwa hilangnya makna persetujuan DPR berarti menghilangkan hak warga negara yang dalam hal diwakili oleh peran DPR sebagai perwujudan kedaulatan rakyat untuk menyatakan pendapatnya tentang suatu perjanjian internasional. 


\begin{tabular}{llrr}
\hline \hline Volume: & 3 & E-ISSN: & $2655-1942$ \\
Number: & 1 & Terbitan: & Mei 2020 \\
Page $:$ & $99-120$ & &
\end{tabular}

Terhadap Putusan Mahkamah Konstitusi tersebut artikel ini mempunyai pandangan yang berbeda. Sebagaimana telah dibahas sebelumnya bahwa tahap ratifikasi merupakan tahapan yang paling penting dalam seluruh proses pembuatan perjanjian internasional. J.G Starke mengungkapkan bahwa praktik ratifikasi dilandasi oleh alasan-alasan berikut ini: ${ }^{28}$

a. Negara-negara berhak untuk memperoleh kesempatan untuk mempelajari dan meninjau kembali perjanjian internasional yang sebelumnya telah ditandatangani oleh delegasi-delegasinya.

b. Negara berhak untuk menarik diri dari keikutsertaannya dalam suatu perjanjian internasional karena alasan kedaulatannya.

c. Perjanjian internasional harus disesuaikan dengan hukum nasional sehingga sering kali harus mengalami perubahan. Jangka waktu antara penandatanganan dan ratifikasi itu memungkinkan negara-negara untuk meminta persetujuan dari parlemennya.

d. Adanya prinsip demokrasi yaitu bahwa pemerintah harus memperoleh pendapat umum di parlemen mengenai perlu atau tidaknya melakukan ratifikasi terhadap perjanjian internasional.

Pada tahapan ratifikasi ini suatu negara mengikatkan dirinya secara definitif pada suatu perjanjian internasional. Ratifikasi perjanjian internasional berarti membatasi kedaulatan suatu negara maka harus diatur dengan ketentuan-kententuan hukum yang jelas. Pasal $10 \mathrm{UU}$ Perjanjian Internasional telah mengatur mengenai penetapan kriteria atau klasifikasi perjanjian internasional yang memerlukan persetujuan DPR dimana hal ini dimaksudkan untuk menciptakan kepastian hukum dan keseragaman atas bentuk pengesahan perjanjian internasional dengan undang-undang.

Putusan Mahkamah Konstitusi yang menyatakan bahwa Pasal 10 tidak mempunyai kekuatan hukum mengikat secara bersyarat sepanjang ditafsirkan bahwa hanya jenis-jenis perjanjian internasional tertentu harus mendapat persetujuan dari DPR dengan instrumen UU Pengesahan justru membuat kriteria ini menjadi bias. Kriteria perjanjian yang harus mendapatkan persetujuan DPR yaitu "menimbulkan akibat yang luas dan mendasar bagi kehidupan rakyat yang terkait dengan beban keuangan Negara dan/atau mengharuskan

${ }^{28}$ J.G Starke, Op.Cit hlm 602 


$\begin{array}{llrr}\text { Volume: } & 3 & \text { E-ISSN: } & 2655-1942 \\ \text { Number: } & 1 & \text { Terbitan: } & \text { Mei } 2020 \\ \text { Page : } & 99-120 & & \end{array}$

perubahan atau pembentukan undang-undang". Sampai saat ini belum ada peraturan yang memberikan batasan penafsiran batasan kriteria tersebut.

Dalam pertimbangan hukumnya MK hanya memberikan penjelasan bahwa perihal dalam hal apa atau dalam keadaaan suatu materi perjanjian internasional menimbulkan akibat yang luas dan mendasar yang terkait dengan beban keuangan negara dan/atau harus mengharuskan perubahan atau pembentukan undang-undang tidak dapat ditentukan secara limitatif melainkan harus dinilai secara kausistis berdasarkan pertimbangan dan perkembangan kebutuhan hukum secara nasional dan internasional. Maka diperlukan penjelasan lebih lanjut mengenai apa yang dimaksud dalam putusan tersebut sehingga dalam praktik tidak menimbulkan sengketa karena adanya interpretasi/penafsiran yang berbeda.

Perbedaan mengenai interpretasi ini mungkin dapat timbul dari Pemerintah maupun DPR tentang apakah suatu perjanjian harus diratifikasi dengan undang-undang atau cukup dengan Peraturan Presiden. Permasalahan yang masih sederhana pernah timbul terkait dengan permohonan pemerintah kepada DPR pada tahun 2010 untuk mengesahkan Agreement between the Government of the Republic of Indonesia and The Government of the Russian Federation on Military-Technical Cooperation 2003. Pemerintah menilai bahwa perjanjian tersebut termasuk dalam kriteria Pasal 10 UU Perjanjian Internasional karena terkait dengan permasalahan pertahanan. Namun di sisi lain, DPR menilai bahwa perjanjian tersebut meskipun terkait dengan permasalahan pertahanan, perjanjian ini sangat teknis sehingga tidak memerlukan persetujuan dari DPR. Setelah melalui pembahasan akhirnya pemerintah dan DPR menyepakati bahwa perjanjian tersebut pengesahannya cukup dilakukan dengan Peraturan Presiden karena tidak termasuk dalam kriteria Pasal 10 UU Perjanjian Internasional.

Pemohon juga memberikan contoh perjanjian internasional yang seharusnya pengesahannya dengan undang-undang namun dalam praktik pengesahannya dilakukan hanya dengan Peraturan Presiden. Perjanjian tersebur terkait dengan kikutsertaan Indonesia sebagai anggota Asian Infrastructure Invesment Bank (AIIB) yang diratifikasi dengan Peraturan Presiden Nomor 171 Tahun 2015. Pemohon menilai bahwa perjanjian AIIB bukan hanya sekedar bersifat 


\begin{tabular}{llrr}
\hline \hline Volume: & 3 & E-ISSN: & $2655-1942$ \\
Number: & 1 & Terbitan: & Mei 2020 \\
Page : & $99-120$ & & \\
\hline
\end{tabular}

teknis dan procedural tetapi menyangkut keterikatan Indonesia dengan utang luar negeri yang berdampak terhadap keuangan negara. Pengesahan perjanjian AIIB dengan Peraturan Presiden ini menunjukan ketidakselarasan mengenai kualifikasi pengesahan perjanjian internasional melalui undang-undang atau peraturan presiden.

Contoh perjanjian-perjanjian tersebut hanya merupakan sebagian kecil gambaran permasalahan mengenai praktik ratifikasi di Indonesia. Belum adanya penafsiran yang jelas mengenai kriteria perjanjian internasional "yang menimbulkan akibat yang luas dan mendasar bagi kehidupan rakyat yang terkait dengan beban keuangan Negara dan/atau mengharuskan perubahan atau pembentukan undang-undang" ini berpotensi akan menimbulkan permasalahan di kemudian hari karena adanya ketidakpastian hukum.

Ratifikasi merupakan tahapan yang paling penting dalam proses pembuatan perjanjian internasional. Ratifikasi juga memberikan konsekuensi bahwa negara menyerahkan sedikit kedaulatannya kepada suatu perjanjian internasional. Proses ratifikasi bukanlah suatu yang mudah karena menyangkut berbagai aspek kehidupan bangsa. Pada dasarnya Pasal 10 UU Perjanjian Internasional sudah memberikan kriteria atau klasifikasi perjanjian internasional yang bersifat dinamis dan dapat disesuaikan menurut perkembangan dan tantangan hukum ketatanegaraan. Namun dalam perkembangannya masih banyak yang perlu disempurnakan.

\section{KESIMPULAN}

Putusan Mahkamah Konstitusi Nomor 13/PUU-XVI/2018 telah memberikan norma baru dalam penafsiran yang lebih lanjut mengenai ketentuan dalam Pasal 11 UUD 1945. Putusan Mahkamah Konstitusi telah memberikan perbedaan pengertian pengertian persetujuan DPR dan pengesahan merupakan dua proses yang berbeda hal ini merupakan konsekuensi dari perbedaan pengertian pengesahan perjanjian internasional menurut hukum internasional dan pengesahan menurut hukum nasional.

Mahkamah Konstitusi dalam putusannya menyatakan bahwa Pasal 10 UU Perjanjian Internasional bertentangan dengan UUD 1945 dan tidak mempunyai kekuatan hukum mengikat 


\begin{tabular}{llrr}
\hline \hline Volume: & 3 & E-ISSN: & $2655-1942$ \\
Number: & 1 & Terbitan: & Mei 2020 \\
Page $:$ & $99-120$ & & \\
\hline
\end{tabular}

secara bersyarat sepanjang ditafsirkan bahwa hanya jenis-jenis perjanjian internasional tertentu harus mendapat persetujuan dari DPR. Kriteria perjanjian yang harus mendapatkan persetujuan DPR yaitu "menimbulkan akibat yang luas dan mendasar bagi kehidupan rakyat yang terkait dengan beban keuangan Negara dan/atau mengharuskan perubahan atau pembentukan undangundang". Sampai saat ini belum ada peraturan yang memberikan batasan penafsiran batasan kriteria tersebut. Hal ini justru ini berpotensi akan menimbulkan permasalahan di kemudian hari karena adanya ketidakpastian hukum. Perlu adanya revisi terhadap UU Perjanjian Internasional yang memberikan penafsiran serta penjelasan mengenai kriteria perjanjian internasional yang menimbulkan akibat luas dan mendasar yang memerlukan persetujuan dari DPR dalam pengesahannya. Sehingga dapat terbentuk suatu perundang-undangan yang jelas dan menyeluruh untuk memperoleh dasar hukum yang kuat dan menghindarkan kekeliruan atau kemungkinan keragu-raguan yang mungkin terjadi dalam praktik ratifikasi perjanjian internasional di Indonesia. 


\begin{tabular}{llrr}
\hline \hline Volume: & 3 & E-ISSN: & $2655-1942$ \\
Number: & 1 & Terbitan: & Mei 2020 \\
Page : & $99-120$ & & \\
\hline
\end{tabular}

\section{DAFTAR PUSTAKA}

\section{Buku}

Dumoli, Damos Agusman, 2017, Hukum Perjanjian Internasional (Kajian Teori dan Praktik Indonesia), PT.Refika Aditama, Bandung.

Fajar, Mukti dan Yulianto Achmad, 2010, Dualisme Penelitian Hukum Normatif dan Empiris, Pustaka Pelajar, Yogyakarta.

J.G Starke, J.G. yang diterjemahkan oleh Bambang Iriana Djajaatmaja, 2008, Pengantar Hukum Internasional 2, PT.Sinar Grafika, Jakarta

Kusumaatmadja, Mochtar dan Etty R.Agoes, 2013, Pengantar Hukum Internasional, PT.Alumni,Bandung.

Mahmud, Peter Marzuki, 2008, Penelitian Hukum, Kencana Prenanda, Jakarta

Maria SW. Sumardjono, 2014, Metodologi Penelitian Ilmu Hukum, Universitas Gadjah Mada, Yogyakarta.

Mauna, Boer, 2015, Hukum Internasional Pengertian,Peranan, dan Fungsi dalam Era Dinamika Global, PT.Alumni, Bandung.

Soekanto,Soerjono, 2012, Pengantar Penelitian Hukum, Universitas Indonesia Press, Jakarta.

Wayan, I Parthiana, 2018, Hukum Perjanjian Internasional Bagian I, Mandar Maju, Bandung.

\section{Jurnal Artikel}

Ari Wiusang, "Kewenangan DPR dalam Ratifikasi Perjanjian Internasional Pasca Terbitnya Putusan Mahkamah Konstitusi No 13/PUU-XVI/2018”, Pakuan Law Review, Vol.5,No.2, Juli-Desember, 2019. 


$\begin{array}{llrr}\text { Volume: } & 3 & \text { E-ISSN: } & 2655-1942 \\ \text { Number: } & 1 & \text { Terbitan: } & \text { Mei } 2020 \\ \text { Page : } & 99-120 & & \end{array}$

Damos Dumoli Agusman, "Status Hukum Perjanjian Internasional dalam Hukum Nasional RI Tinjauan Dari Perspektif Praktik Indonesia”, Indonesian Journal of International Law, Vol 5 No 3, April, 2008

Kamrmila Hippy, "Praktik Ratifikasi Perjanjian Internasional di Indonesia", Lex Administratum, Vol.I, No.2, April, 2013.

\section{Internet}

Hukum online, "Putusan MK UU Perjanjian Internasional:Apa yang diubah", https://www.hukumonline.com/berita/baca/lt5c79077b8ebcb/putusan-mk-uu-perjanjianinternasional--apa-yang-diubah-oleh--damos-dumoli-agusman/“, diakses pada tanggal 12 Januari 2019 pukul 17.00 wib

Kontan, "Kementrian Luar Negeri: Putusan MK perkuat revisi UU Perjanjian Internasional”, https://nasional.kontan.co.id/news/kementerian-luar-negeri-putusan-mk-perkuat-revisi-uuperjanjian-internasional, diakses pada 10 Februari 2020 jam 15.00 wib

\section{Peraturan Perundang-Undangan}

Undang-Undang Dasar Negara Republik Indonesia tahun 1945

Undang-Undang Nomr 24 tahun 2000 tentang Perjanjian Internasional (Tambahan Lembaran Negara Republik Indonesia Nomor 4012)

\section{Putusan Pengadilan}

Putusan Mahkamah Konstitusi Nomor 13/PUU-XVI/2018 perihal Pengujian Undang-Undang Nomor 24 Tahun 2000 tentang Perjanjian Internasional terhadap Undang-Undang Dasar Negara Republik Indonesia Tahun 1945 